\title{
Currency and Monetary Arrangements for East Timor
}

\author{
Gordon de Brouwer* \\ Australian National University \\ revised draft, 5 April 2001
}

\begin{abstract}
East Timor faces an important decision in choosing its currency and monetary arrangements. This paper sets out the policy issues in deciding whether to fix or float the currency, including implications for the choice of the framework for monetary policy. It assesses the relative merits of different fixed exchange-rate regimes, including the standard peg, currency board and 'dollarisation' (by which a country decides to use another country's currency as its own), and of different target currencies, including the euro, the rupiah, the US dollar and the Australian dollar. It argues that East Timor should adopt a strongly fixed exchange rate. The best option is probably dollarisation using either the US dollar or the Australian dollar.
\end{abstract}

\footnotetext{
Professor of Economics, Australia Japan Research Centre, Asia Pacific School of Economics and Management, and Division of Economics, Research School of Pacific and Asian Studies, Australian National University. Comments welcome to gordon.debrouwer@anu.edu.au. I am grateful for comments from Manuel Coutinho, Peter Drake, Mardi Dungey, Hal Hill, Jan van Houten, Bob Rankin, Klaus Rohland, and Antonio de Almeida Serra. All errors are mine.
} 


\section{Currency and Monetary Arrangements for East Timor}

\section{Introduction}

An important decision in the design of macroeconomic policies in any country is the choice of currency and monetary regime. Getting this right at the outset is crucial for securing long-term economic and social stability.

Not surprisingly, there is an enormous literature on currency and monetary regimes, and an enormous range of country experiences to draw on. This paper sets out a policy menu for East Timor based on this literature, constructed in a way that suits East Timor's particular characteristics and needs.

There are two fundamental decisions to be made in choosing a currency and monetary regime. The first is whether to have a fixed or flexible exchange-rate regime. The advantages of a fixed exchange rate are that it can provide stability in an important economic or trade relationship, it can stabilise and anchor inflation, and, because it generally means accepting the interest rates of the target-country, it eases the burden of setting domestic monetary policy. The advantages of a flexible exchange rate are that it can be adjusted to stabilise domestic income as economic circumstances change, and it enables the local authorities to set interest rates suited to domestic conditions. The decision to fix or float depends on weighing these sets of advantages against each other, and assessing which works in practice.

The second decision is the detail of the arrangements. If policymakers fix the exchange rate, they need to decide how 'fixed' it is going to be. They can choose a standard peg (with the exchange rate adjusted from time to time as circumstances change), a currency board (where it is very hard to adjust the exchange rate), or officially adopt another country's currency as their own, that is 'dollarise'. If policymakers float the exchange rate, they have to put in place the extensive resources needed to be able to determine their own interest rates and they have to decide how 'managed' the float will be. The institutions, infrastructure and skills needed to support these policy choices vary substantially between the various options, with a currency board and 'dollarisation' being the least demanding.

The paper is structured in the following way. Section 2 summarises some of the features of East Timor's economy that are relevant to the choice of currency and monetary regime. Section 3 looks at the first decision: to fix or float the exchange rate, and what this means for monetary policy. 
Section 4 assesses different types of fixed exchange-rate regimes, namely the standard peg, currency board, and 'dollarisation'. Section 5 looks at which countries would be suitable pegging partners for East Timor. Section 6 concludes by offering an assessment.

\section{Characteristics of East Timor's Economy}

The choice of a currency regime depends on the characteristics of the economy. There are three economic aspects of East Timor to note.

First is the type of economy. East Timor is a very small economy by world standards. It is a largely agrarian, developing economy. It is one of the poorest countries in Asia, with a national income thought to be about \$US300 million, or \$US380 a head. Even with foreign aid and future oil revenue, it will have at best only modest financial resources to support the administration of any currency and monetary regime.

East Timor has a narrow export base, currently concentrated in coffee, oil, sandalwood and marble, and is thought to have substantial oilrevenue potential. The prices of these commodities - and hence export income - are highly variable. East Timor has some tourism potential but it is completely undeveloped at this stage.

The second aspect is that institutional capacity in East Timor is low. It has a very small population, about 800,000 people, and its labour force is estimated at less than half that, about $340,000 .{ }^{1}$ Most of the workforce is not well educated. Before independence, most of its bureaucratic infrastructure was administered by Indonesians rather than East Timorese. While there was a substantial number of educated East Timorese living outside East Timor during Indonesian rule, there are not many economists. In short, there are scarce staff resources to support the administration of any currency and monetary regime.

Finally, current arrangements and practices are relevant because it is important to limit the costs and difficulties of transition from UNTAET administration to local rule. Under Regulation 2000/7, the US dollar became legal tender in East Timor for all official and private transactions from 24 January 2000. While all official transactions must now be made in US dollars, people are free to use any currency they wish in private transactions, with the proviso that they cannot refuse to use US dollars if one party so wishes. This means that the rupiah, Australian dollar, Singapore dollar, baht and escudo are also in circulation. The rupiah is by

\footnotetext{
1 Timor Profile, Sydney Morning $\quad$ Herald, 7 October 1999 (www.smh.com.au/news/content/timor).
} 
far the preferred currency of use by most East Timorese because it is familiar and can be used in small transactions.

One socio-economic factor that should be kept in mind is national sentiment. East Timor was a Portuguese colony from 1520 to 1975 and an Indonesian province from 1975 to 1999. Understandably, East Timorese have a deep and powerful desire to assert and protect their national sovereignty. A country's currency is sometimes seen as a sign of its independence and sovereignty, and it is important to address this issue in discussing the choice of currency regime.

\section{Fix or Float?}

The first decision in selecting a currency and monetary regime is whether to fix or float the currency. For a small economy like East Timor, there are two main issues to consider in making this choice.

\section{Which regime is more stabilising?}

The first is assessing the relative merits of having a fixed or flexible exchange rate. The decision to fix or float turns ultimately on whether having an independent exchange rate provides a country with a means to stabilise its economy as the external economic circumstances it faces change. If being able to change the exchange rate helps stabilise the economy, then having a more flexible regime is, in principle, helpful and preferable. $^{2}$

The exchange rate is a relative price - the value of one country's currency relative to that of another. As circumstances change, it may be appropriate that these changes are reflected in the exchange rate. There are two types of 'circumstances' that warrant consideration: economic circumstances and political circumstances.

\section{Changing economic circumstances}

Changes in a country's external economic environment can have implications for the exchange rate. For example, if the price of a country's exports falls substantially — say because foreign demand for those exports fell or there was world-wide excess supply of those commodities - then the country suffers a fall in its terms of trade, export income, and GDP (all else given) If the exchange rate depreciates in

\footnotetext{
2 See Friedman (1953), Isard (1995) and Mussa, Masson, Swoboda, Jadresic, Mauro and Berg (2000) for clear arguments on the pros and cons of fixed and floating exchange rates.
} 
response to this 'shock', then the value of exports does not fall by as much (if at all) in terms of local currency, and export income and GDP are stabilised. Flexibility in the exchange rate is likely to be important for countries which experience large movements in the prices of their exports or imports.

In principle, this is relevant to East Timor because its export base is concentrated in a few volatile commodities. Figure 1, for example, plots the average prices for East Timor's two main exports, coffee and crude oil, over the 1990s. Both prices have fluctuated substantially in this period. If policymakers want to stabilise export income, then they would need to either depreciate the currency when commodity prices fell (and appreciate the currency when they rose) or fix to a currency which also depreciated when commodity prices fell (and appreciated when they rose).

Figure 1: Average Oil and Coffee Prices

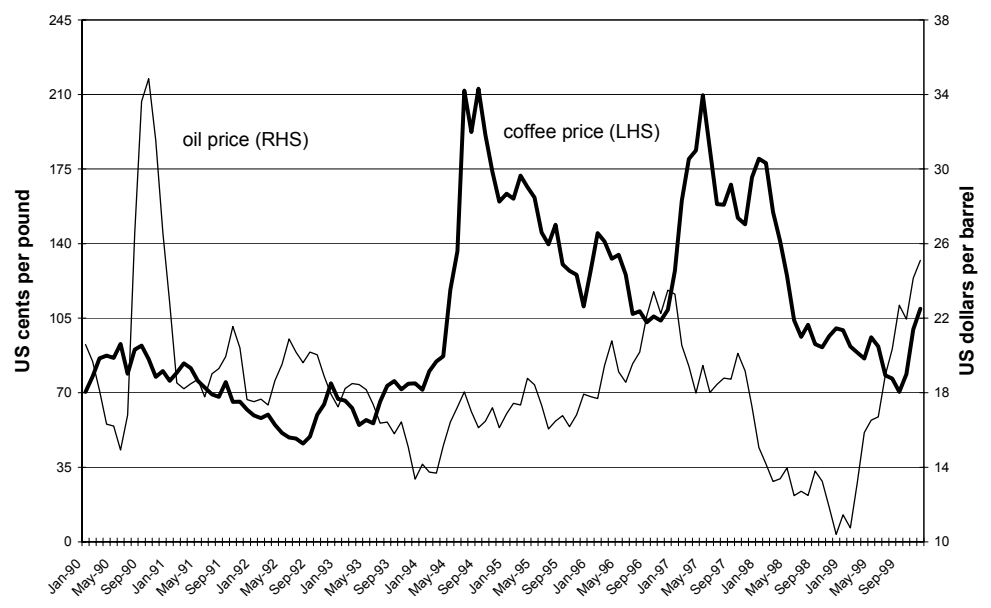

Source: IMF International Financial Statistics

While this analysis suggests that some flexibility in the currency regime may be helpful there are two serious obstacles to a country like East Timor being able to adopt an independent currency in practice.

The first is that the country is too small to be able to rely to any substantial degree on the foreign exchange market to set the exchange rate. A freely floating exchange rate is not a viable option for a very small country because its foreign exchange market lacks liquidity, making the currency vulnerable to sharp erratic movements. This appears to be the case for Pacific Island nations (de Brouwer 2000), and would most likely be the case for East Timor. This means that a floating exchange rate would need to be highly managed, which leads to the second obstacle. 
Managing a floating exchange rate is challenging. It requires a large number of staff with substantial expertise. Australia, which does not manage its exchange rate but does occasionally intervene in the foreign exchange market when conditions become disorderly, has 15 or so expert staff devoted to its market operations and analysis. Even this number of staff is a big ask for a country the size of East Timor. It also requires a well-articulated policy framework, sufficiently developed financial markets, and, importantly, a system free from political interference.

\section{Changing political circumstances}

The second set of circumstances that can affect the exchange rate is political uncertainty and instability (which economists would call a 'nominal shock'). Of particular concern here is the potential for political uncertainty and instability to destabilise the exchange rate.

Even in very developed markets, political uncertainty and risk can at times put downward pressure on the exchange rate. But when political tensions and instability are high, the cost in exchange rate instability can be substantial. This is most obvious in the recent experience of a number of Pacific Island nations - including Fiji, PNG, the Solomon Island and Vanuatu - with the value of their currencies falling as a result of political instability (de Brouwer 2000). Political instability affects both floating and fixed exchange rates, but the effect is probably felt more quickly in the case of floating regimes. The only fixed exchange-rate regime which insulates a small country's exchange rate from political instability is 'dollarisation': because a separate currency does not exist, political instability cannot affect its exchange rate.

\section{The exchange rate and monetary policy}

The second issue is the relationship between currency regime and the monetary regime. The monetary regime is largely a consequence of whether a country fixes or floats its currency. The general principle underpinning much of the literature is what economists call 'the impossible trinity', namely that a country where capital can move in and out cannot have both a fixed exchange rate and an independent monetary policy. ${ }^{3}$

\footnotetext{
3 The decision to fix or float the exchange rate depends in part on how easy it is for capital to move across borders. If capital is not mobile, then conceptually a country can fix its exchange rate and set its own interest rates. The mobility of capital is largely related to the regulatory system, that is, whether effective capital controls are in place or not. Capital controls generally make the cross-border movement of capital more difficult, but this really depends on how effective the controls are. Controls are not effective if they are not enforced, if they are unenforceable, or if they can be easily avoided (as
} 
If capital is mobile and the country chooses a fixed exchange rate, then it generally has to accept the interest rates of the country to which it fixes its currency. In this case, the authorities largely lose their discretion to set interest rates. If the country pegs to a low-inflation currency, its inflation rate and economic cycle will tend to converge to that of the target economy. Labour market flexibility is important under a fixed exchange rate because it provides the 'shock absorber' which reduces the adverse impact of economic disturbances on output and employment.

If a country floats its currency, then in theory it can choose its own interest rates, although the evidence is that most developing countries are not be able to do this in practice (Hausman, Gavin, Pages-Serra and Stein 1999). In theory, the freedom to choose its own interest rates means that a country can choose its own inflation rate, although often many of the factors that affect inflation are global and it is hard for countries to resist global trends in inflation, like the oil price shocks in 1975 and 1979, and the global disinflations in the early and the late 1990s. At least for Latin American countries, the evidence is that countries with more flexible exchange rate arrangements have performed worse than those with less flexible arrangements (Hausmann et al. 1999). Labour market flexibility is also important under a flexible exchange rate. When the exchange rate depreciates in the event of an adverse economic event, it only stabilises output if prices and wages do not rise by the same proportion, that is, if the real exchange rate depreciates also. A labour market which prevents 'real' wages from adjusting to changes in economic circumstances makes the adjustment fall on output and employment.

The challenge for a country which wants to set its own interest rates is to ensure that it has infrastructure adequate to the task. This is complex. First, the country needs to have a clear monetary-policy framework in place, with a coherent consistent set of aims and the necessary tools and markets to be able to achieve them. Specifically, the key standard aim of monetary policy is to maximise steady-inflation economic growth, and the authorities need to understand the processes that underpin this and have the instruments to influence them.

Second, it needs to have the staff, expertise, and facilities (buildings, structures and capital equipment) in place to decide and implement policy. In either respect, East Timor does not appear at the moment to have the necessary resources to conduct an independent monetary policy (McLeod 2000).

tends to be the case). The current consensus is that capital controls designed to stop capital leaving a country are not generally effective, especially in a crisis, but that controls on inflows to prevent some speculative inflows can be. Capital controls also require a bureaucracy, and generally a growing one, to enforce the restrictions. 
One crucial condition for a stable monetary system under either both fixed and floating exchange-rate regimes is the separation of monetary management from the budgetary process. The monetary authority should not be called on to print money to fund government expenditure. The consequence of making the monetary authority fund a fiscal deficit is inflation - and often hyperinflation.

The system needs to be robust to the array of political and social pressures that arise in all countries, but which can be particularly fierce in developing countries. The experience of Papua New Guinea since independence in 1975 provides some valuable insights into the sorts of serious pressures and problems that can arise.

When PNG gained independence in 1975, it established its own currency, the kina, and its own monetary authority, Bank Papua New Guinea (BPNG). From 1975 to 1994, the kina was fixed to a basket of the currencies of its major trading partners and revalued from time to time to contain inflation. The system came undone in 1994 in a serious fiscal crisis, and the fixed exchange-rate regime collapsed and shifted to a managed float. The currency has since lost three-quarters of its value against the Australian dollar.

The integrity of the central bank has also been undermined. While BPNG has had some excellent staff over time, it has also suffered a continual and serious shortage of skilled staff, something that Heinz Arndt warned about well in advance of PNG's independence (Arndt 1971). More seriously, BPNG has also been forced to finance the government's fiscal budget, which fed already-widespread corruption, created substantial inflationary pressures, and was a contributing factor in the collapse of the kina (Duncan and Xu 2000).

This is not meant to cast any doubt at all on the integrity of East Timor's political leaders. Rather, it is meant to show that the system that is put in place needs to be resilient to a whole range of pressures, including political ones, long after independence has been achieved. PNG's system worked well until the 1990s but it came undone because it was not robust to intense rent-seeking behaviour and political pressure. ${ }^{4}$

\footnotetext{
Duncan (1999) argues that part of the problem in PNG was that its great resource wealth led to a focus on acquiring wealth rather than creating it. He argues that this has implications for oilproducing East Timor.
} 


\section{How to fix?}

If East Timor fixes its exchange rate, the next question is how should the currency be fixed? The degree of fixity is a matter of choice. There are three options: a standard peg, a currency board, or 'dollarisation'.

Under a standard peg, East Timor would have its own currency and would fix its value to another currency or basket of currencies. It would retain the option of changing the rate as economic circumstances changed. East Timor would need a stock of foreign exchange reserves to support this system. The conventional approach is to require reserves to be equal to at least three months of imports.

Under a currency board, East Timor would have its own currency and would fix its value to that of another currency. Under a currency board, a country has to back all of its currency in circulation with reserves of the target currency (and usually there are excess reserves). For example, if it set its currency - call it the East Timor dollar for convenience - equal to one US dollar, and if it had \$ET1 million in circulation, then it would have to hold at least \$US1 million in reserves.

A currency-board mechanism would automatically tie East Timor's interest rates to at least equal those of the target country. In this example, if East Timor's interest rates fell below those of the United States, people would see that the value of the two currencies is fixed but that they can earn more on US dollar deposits. They would sell ET dollars for US dollars, which would create a shortage of ET dollars and push up East Timor's interest rates, to at least the level of US interest rates. In reality, East Timor's interest rates would most likely be higher than US interest rates because of a risk premium.

The automaticity of this interest-rate equalisation mechanism depends on people believing that the value of the two currencies is fixed and will not change. If people thought that the ET dollar was going to depreciate, for example, then they would demand higher interest rates on their ET dollar deposits. For this reason, it is almost impossible to change the fixed exchange rate under a currency board system because such a change would undermine the credibility of the system and likely destroy it. For that reason also, currency boards are seen as a rigid or strong form of fixed exchange-rate arrangement.

'Dollarisation' means that a country officially uses the currency of another country as its own. It is called 'dollarisation' because most of the current debate is about countries, particularly those in Latin America, using the US dollar, but it could involve the use of any currency. 'Dollarisation' means that the country's exchange rate is permanently fixed to that of the other and that local interest rates are the same as that 
of the target country (although interest rate margins on deposits and loans may differ). It is difficult to exit 'dollarisation' since it takes time, money and effort to set up an alternative system. It is, therefore, seen as the most credible of fixed exchange rate systems.

Each of these ways to fix the exchange rate has relative merits. The advantage of the standard peg is that it can it be adjusted as economic circumstances change. When there are substantial changes in foreign demand for local goods and services or in the price of key export commodities, for example, then the exchange rate can be adjusted to keep the domestic value of exports relatively stable. A currency board and 'dollarisation' do not allow the authorities such a degree of discretion to change the exchange rate.

The main disadvantage of the standard peg is the flipside of its advantage. Because it is more flexible, it is also substantially less credible and so interest rates under standard pegs are typically higher than under currency boards or dollarisation. ${ }^{5}$ Rivera-Batiz and Sy (2000) find that standard pegs perform less well over the long term than currency boards: interest rates and inflation are higher, and economic growth is lower, under a standard peg. Institutional detail does matter to performance. While a standard peg provides more discretion to deal with changing economic circumstances than the other fixed exchange rate alternatives, the general evidence suggests that this discretion has not been used well.

The key advantage of a currency board and dollarisation over a standard peg is credibility. This credibility means that countries which want to stabilise inflation and inflation expectations by targeting to a low inflation country are more likely to achieve their aim by setting up a currency board or 'dollarising' to a low inflation country. This is enhanced by the fact that the fiscal authorities cannot require the monetary authority to print money to fund a budget deficit under a currency board or 'dollarisation'.

This is particularly important for countries coming out of a crisis or in transition. A number of countries adopted currency boards in the 1990s - Argentina in March 1991, Estonia in June 1992, Lithuania in April 1994 and Bulgaria in July 1997 - and their decision was based on the desire to gain credibility. The evidence suggests that they were mostly successful (Rivera-Batiz and Sy 2000).

\footnotetext{
$5 \quad$ Perhaps the best recent example of 'dollarisation' leading to a reduction in interest rates to those of the target country is the lowering and convergence of European short and long term interest rates to German levels in the lead up to the introduction of the euro in 1999, which can be viewed as a subtle form of 'deutschemark-istion' of Europe.
} 
The other advantages of a currency board and 'dollarisation' over a standard peg are that they are easier to run, since they reduce the discretion of policymakers, and they require substantially less administration and support. In both these respects, 'dollarisation' is the least expensive option, since it does not provide for any local policy discretion and it requires no local administration.

The other crucial difference between a currency board and 'dollarisation' is the credibility of the regime. 'Dollarisation' is more credible than a currency board. While the exchange rate is less likely to be changed under a currency board than under a standard peg, there is still the possibility that the rate will be changed under a currency board because the authorities retain the power to change the rate at their discretion. ${ }^{6}$ The exchange rate under 'dollarisation', however, is not subject to immediate change by the authorities, since the authorities need to design, print, and distribute a local currency before it can replace the existing currency and change the exchange rate. The authorities can reverse 'dollarisation', but if they want to do so they have to plan well in advance, making an unexpected change in the exchange rate an extremely unlikely event.

This means that in periods of uncertainty, such as when pressures emerge for a devaluation, a currency board will be tested by speculators - who, it is worth noting, can range from the likes of offshore hedge funds to local residents and business people. The most recent examples are the intense speculative pressures Hong Kong and Argentina experienced during the Asian financial crisis. Their currency board arrangements remained in place but speculation about whether they would hold or not pushed interest rates up to extreme levels at times. This cannot happen under 'dollarisation' because there is nothing to speculate on. Interest rates are expected to be lower on average under 'dollarisation' than a currency board, and this is a key reason why Argentina is now so interested in replacing its currency board and officially using the US dollar.

Because it is so difficult to change the exchange rate under 'dollarisation', it is a serious policy option for small countries which are concerned about limiting the discretion of future policymakers and the possibility of the 'PNG problem' occurring, as outlined above. In this respect, it is worth noting that there is a growing body of opinion that PNG should replace the kina with the Australian dollar (Xu 1999; Duncan and $\mathrm{Xu} 2000$ ) and that the Pacific Island nations should replace

\footnotetext{
6 That said, there are few cases of exit from a currency board, and those tend to be newly independent nations breaking from their former colonial master.
} 
their currencies, where they have not done so already, with the Australian dollar (de Brouwer 2000).

There are three potential disadvantages with 'dollarisation', but none of which are insurmountable. The first possible disadvantage, which also applies to a currency board, is that the authorities cannot bail out banks unless they have the necessary excess foreign exchange reserves. This is not really a problem in East Timor, at least for the foreseeable future, since all the banks operating there are foreign (either Australian or Portuguese) owned and supervised. Not having the capacity to bail out banks can be an advantage if it makes the banks manage their risks better, reducing what economists call 'moral hazard'.

The second possible downside with 'dollarisation' is that the authorities lose seignorage, that is, the revenue earned by making currency. Governments make a profit from making currency because the cost of making currency is substantially less than its face value. Because the government is not printing its own notes and minting its own coins if it 'dollarises', it does not make seignorage, the target country does. This is not really a problem so long as the target country agrees to transfer the appropriate amount of seignorage revenue to the country using its currency.

The third possible problem with 'dollarisation' is that it may be interpreted as a loss of sovereignty. Having a local currency often tends to be seen as a symbol of a nation's independence, and its replacement by the currency of another country may be seen as a loss of economic sovereignty. It is important to note that in many instances this is not the case.

Consider three examples. The European Union's 15 members, for example, have been able to agree to replace 14 national currencies with the euro. Some other European countries are eager to join. Twenty-eight countries, most of them in Latin America, already officially use the US dollar, and others, including Argentina, are on the public record as saying that they want to follow suit. Closer to home, Nauru, Kiribati and Tuvalu are independent Pacific Island nations but use the Australian dollar. As these examples show, many countries feel able to 'dollarise' without loss of sovereignty or prestige, and indeed welcome the economic benefits that it can confer. Ultimately, whether 'dollarisation' is seen as an affront or an affirmation of economic independence probably depends on how politicians choose to play the issue. 


\section{Who to fix to?}

If East Timor chooses to fix its currency, in any of the forms outlined in the previous section, to which currency should it fix?

One option that would normally be considered in a discussion of fixed exchange rates is whether to peg to a basket of the currencies of the countries that are important to the country concerned. When a number of countries are important trade partners, for example, pegging to a basket of these currencies helps stabilise the exchange rate on average. But in East Timor's case, there are no trade data and matters are in a state of flux. The exchange rate under a basket peg would be subject to frequent realignment for a number of years, reducing transparency, increasing uncertainty, and increasing the risk of the 'PNG problem' arising. If 'dollarisation' becomes the preferred option, a basket peg is irrelevant.

There are four serious possible currencies that East Timor could peg its currency to or use to 'dollarise'. In no particular order, they are the euro, the rupiah, the US dollar, and the Australian dollar. There are three other currencies in circulation in East Timor but it is hard to see them as serious contenders. The escudo is used in East Timor but only in very small amounts and will disappear in 2002 when it is replaced by the euro. While the baht is also currently used in East Timor, it is only in very small amounts and is used exclusively by Thai militiary personnel who are part of the peacekeeping forces. The Singapore dollar is also used in East Timor but, while the Monetary Authority of Singapore has an excellent record on inflation and the Singapore dollar is relatively stable, the MAS does not generally support the international use of its currency, which would be necessary to build up East Timor's reserves, and the currency is not heavily traded internationally. The MAS would also be unlikely to encourage the use of its currency in East Timor because of difficulties this may create with Indonesia.

To be a suitable target, the foreign currency would need to meet four key criteria: be a reliable low-inflation anchor, have a meaningful economic connection to East Timor, be an internationally usable and stable currency, and, in the case of 'dollarisation', be acceptable and practical as a medium of exchange. Based on these criteria, the four currencies listed above have different relative strengths.

While the euro does not currently exist, it will come into circulation from January 2002 and replace the escudo which is in use in East Timor. The euro basically meets the criteria listed above for a suitable currency target. It would provide a solid anchor for inflation since, in the tradition of the Bundesbank, the European Central Bank is an avowed inflation fighter (although some would argue perhaps too aggressively). Its 
connection with East Timor is that the EU and Portugal are the main bilateral aid donors and that East Timor is a former colony of Portugal. The euro is a major world currency.

But there are reservations with its use. While the EU and Portugal are the main aid donors to East Timor, this is administered by the United Nations and is denominated in US dollars rather than euro, although the denomination of aid may change in the future. Moreover, most of East Timor's aid money is used for the purchase of equipment overseas and payment of UN salaries rather than for current local expenditure; the currency denomination of aid money does not seem to be so relevant to the choice of currency peg.

Europe is also a long way from East Timor. This would make logistical support difficult and expensive, especially if East Timor were to 'dollarise' using the euro: the freight of coins in particular is timeconsuming and expensive. The distance from Europe also raises the issue of commitment. On the one hand, it is natural to ask whether the EU will at some time in the future reduce its focus on East Timor, as Portugal did in the 1960s and 1970s. But, on the other hand, it is also a device to keep foreign interest in East Timor.

The rupiah is currently the most widely used currency by East Timorese themselves, as opposed to the foreigners in East Timor. Its main advantage as target currency is that Indonesia's proximity, common border, and close connections are likely to make Indonesia East Timor's main trading partner once relations have normalised. ${ }^{7}$ If East Timor were to 'dollarise', the rupiah would also be a very easy logistical choice because it is already widely accepted and is relatively cheap to transfer.

But there are several obvious disadvantages with the rupiah. It is not a stable currency. Indonesia is neither politically or economically stable, and it cannot offer the prospect of low and stable inflation. Finally, the historical relationship is such that pegging to the rupiah, let alone using it, would be a difficult political choice. While economic relations with Indonesia will likely continue to be very important to East Timor, there is a wider need and desire to assert East Timor's independence from Indonesia.

The US dollar meets all the criteria of a target currency. It is the world's most important currency and an increasing number of countries are

\footnotetext{
East Timorese officials estimate that about Indonesia currently accounts for about 20 per cent of East Timor's trade (with Australia the major trading partner with a share of about 40 per cent). The Indonesian share will increase substantially after independence when UNTAET is dissolved and many of its employees and associates leave, and once cross-border trade between East Timor and Indonesian West Timor recovers.
} 
pegging to it or using its currency as their own. The world prices of commodities, including oil and coffee, are all denominated in US dollars. Strategically, fixing to, or using, the US dollar will help keep US focus on East Timor, although this should not be over-emphasised. The US dollar is also the current legal tender in East Timor, so the transition costs should be less than otherwise. ${ }^{8}$

There are two problems with the US dollar. If East Timor were to use the US dollar as its own currency, one problem would be the logistics and cost of transporting notes and coins from the United States. Low denomination currency is especially important for small transactions by the East Timorese; a bunch of bananas, for example, costs about 3,000 rupiah, or US30 cents. US coins are not widely used in East Timor currently rupiah notes and Australian coins are used for change — but the US dollar cannot be used without an accessible set of low denomination currency. The problem is not with US dollar notes but US coins, which are very difficult, heavy and expensive to move, and many of which are given names but not numbered.

One way around this problem is for East Timor to use its own coins so long as they are fully backed by reserves of US dollars. The precedent for this is Panama which is officially dollarised but uses its own coins (Schuler 1999). These coins could be minted for the East Timorese government in a country close to East Timor, such as at the Australian mint in Perth.

Apart from providing a low denomination currency and reducing logistical difficulties, minting East Timor coins for denominations below one dollar has a number of advantages. Coins are much more durable and long-lasting than notes and, if clearly numbered and properly sized, are easy to use. They are likely to be easier to read and use than most of the rupiah notes in circulation in East Timor, especially in the remoter parts of the country where many of the rupiah notes are said to be disintegrating and illegible. It also would enable East Timor to have, albeit partially, some localisation of its currency without serious risk of loss of monetary control. ${ }^{9}$

\footnotetext{
8 An important transitional issue is the logistics of replacing the rupiah with US dollars. This has a range of dimensions. It would require a proper education and exchange program, as well as obtaining the agreement of Bank Indonesia to convert existing rupiah with US dollars. This latter point is complicated not only by the sensitive politics and negotiations required for such agreement, but also practical issues like the illegibility and poor condition of rupiah notes in circulation in East Timor, notes which have been taken out of circulation but which are still widely used in East Timor (like 500 and even 100 rupiah notes), counterfeits, and the legitimacy of rupiah notes which are thought to have been stolen by the Indonesian military from Bank Indonesia and laundered in East Timor.

9 They are also much more expensive to make than notes, which means that the incentive to mint more coins to earn seignorage is much lower.
} 
The second problem is that the US dollar is very strong, which some fear would price East Timorese products out of the market, especially in comparison to Indonesian goods. This is a legitimate concern but needs to be kept in perspective. The US dollar is widely thought to be overvalued, and so has substantial scope to depreciate in the future, which would help exports and import-competing goods. There is also scope for domestic prices to fall in East Timor, once better transport and information infrastructure is established outside Dili, trade with West Timor is normalised, and the number of foreigners gets smaller after UNTAET is disbanded.

Moreover, while international competitiveness is obviously important, monetary policy must ultimately be directed at domestic price stability, and the exchange rate regime needs to support this (Drake 1983). An implication of this is that the authorities need to ensure that East Timor's labour markets are flexible enough, so that wages can fall when prices fall, and that labour costs can fall when adverse economic disturbances occur, so that their negative effects on output and employment are as small as possible.

The final alternative is to fix to the Australian dollar. The Australian dollar also fits all the criteria. It meets the inflation anchor requirement. Australia's central bank has a robust but flexible medium-term inflation target regime in place, and inflation has averaged about 2 per cent since 1990. The Australian dollar is the seventh most traded currency in the world and it is straight-forward to hedge Australian-dollar currency risks. While the Australian dollar does fluctuate substantially, its volatility is similar to that of the major currencies.

Australia also has a meaningful economic connection to East Timor. While data are not available, observers suggest that many of the foreign goods and services available in East Timor are sourced from Australia and are denominated in Australian dollars. While Australia's share of trade is expected to decline as things normalise in East Timor, Australia will remain one of its most important partners. After the rupiah, the Australian dollar is the most widely used currency for private transactions. Australia is also close to East Timor, so there are not the same logistical problems and costs involved in pegging to, or using, the Australian dollar.

The Australian dollar is widely regarded as a commodity currency, tending to appreciate as commodity prices rise and depreciate as they fall. This is an important stabilising influence on inflation and economic growth in Australia because it tends to constrain aggregate demand when world trading conditions are good and boost it when world trading 
conditions are poor (Blundell-Wignall 1993). This is potentially relevant to East Timor because its main exports are likely to be commodities, specifically crude oil and coffee. Pegging to the Australian dollar may then offer the prospect of stabilising East Timor GDP in the event of price changes to its commodity exports, so long as the movement in these commodities is related to movements in commodity prices in general and the Australian dollar in particular.

Figures 2 and 3 plot the Australian dollar against crude oil prices and coffee prices respectively. Two observations can be made. First, the Australian dollar typically depreciates when oil prices fall (and appreciates when oil prices rise), but there is little obvious relationship between the Australian dollar and coffee prices: in the 1990s, the correlation of the Australian dollar and oil prices is a statistically significant 0.5 , but is an insignificant 0.1 for coffee prices. This is hardly surprising because Australia is a net exporter of energy but net importer of coffee. Second, while the correlation between oil prices and the Australian dollar held in the 1990s, it has not been evident in the past few years. The correlation tends to be unstable.

The upshot is that, while on historical evidence, the Australian dollar would be a good choice as target peg because it tends to stabilise domestic income in local currency terms when commodity prices move, this is not a robust or stable relationship.

Figure 2: Crude Oil Price and the Australian Dollar

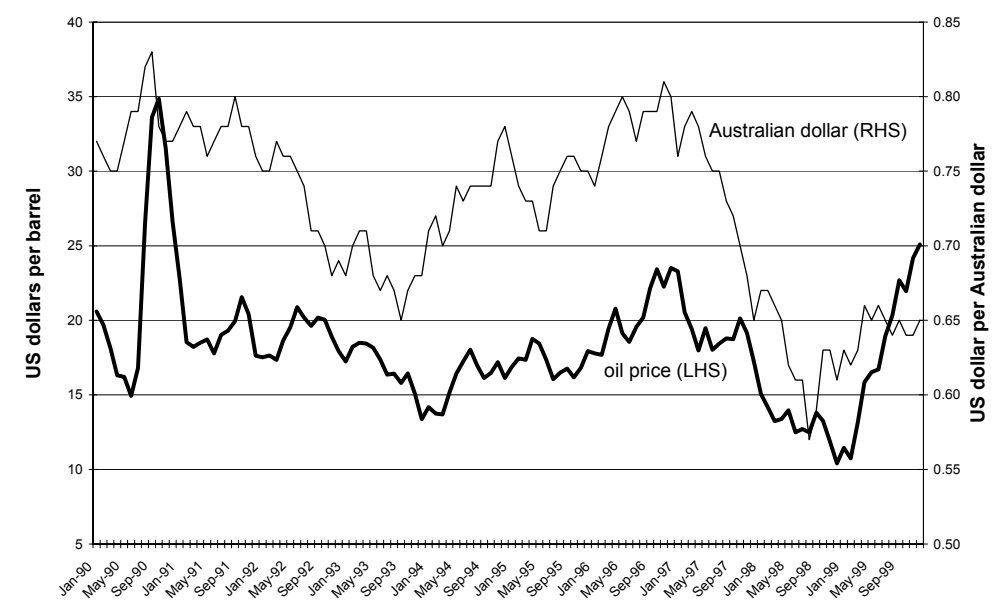

Source: IMF International Financial Statistics 
Figure 3: Coffee Price and the Australian Dollar

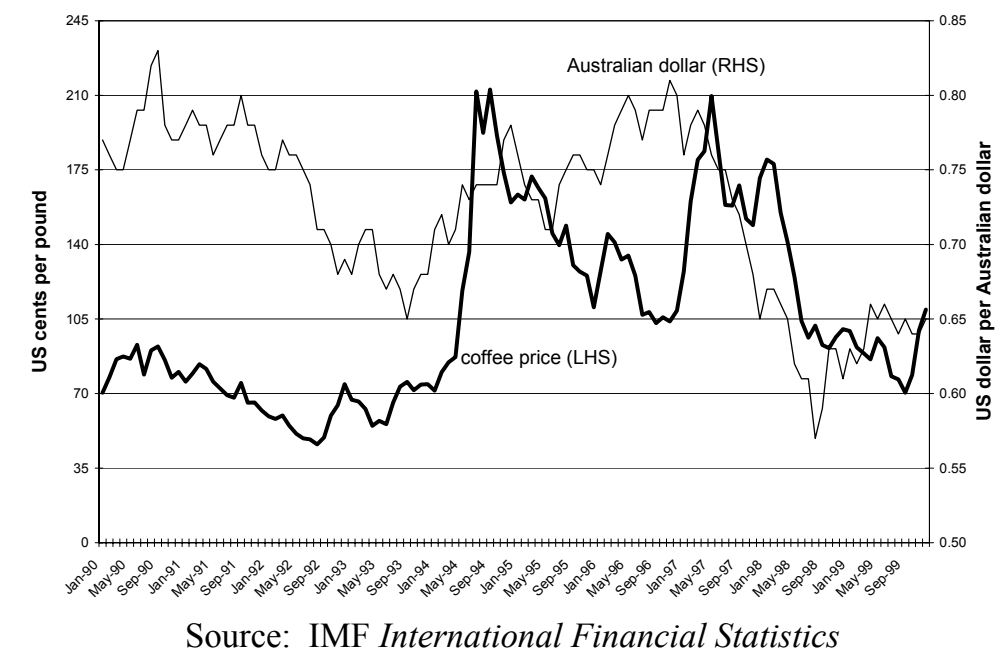

There are three downsides in pegging to, or using, the Australian dollar. The first is the importance of exchange-rate stability in the first few years of the regime. The Australian dollar is currently about 50 US cents, which most observers would say is excessively depreciated. It is likely that it will appreciate over the next year or so. The US dollar may be a better target, although there is substantial risk that it will depreciate.

The second downside is that pegging to, or using, the Australian dollar could adversely affect East Timor's relations with Indonesia, as well as those between Australia and Indonesia. Indonesia may resent such a link with Australia, and may (incorrectly) perceive it as an attempt by Australia to extend its sphere of influence at the cost of Indonesia's. From a strategic point of view, East Timor has substantial interest in seeing the normalisation of relations with Indonesia. Australia wants to regularise its relationship with Indonesia and would not appear at this stage to welcome formal use of the Australian dollar.

Finally, pegging to, or using, the Australian dollar may contribute to a mentality of dependence in East Timor. Given the closeness to Australia and the experience of the past few years, Australia is likely to extend considerable aid and other resources over many years to come, even as the contribution of other donors wanes. From East Timor's perspective, it is important to keep as many other countries interested in, and aware of, its circumstances as possible. Using a currency other than the Australian dollar as peg or currency of choice may reduce the mentality of dependence on Australia and retain the focus of other important countries on East Timor. 


\section{An Assessment}

East Timor is a small low-income developing economy with limited financial and human resources and a narrow commodity export base. While the decision about which currency and monetary regime to adopt is obviously a matter for East Timor to decide, the country's economic and social features suggest that the set of feasible choices is relatively narrow.

In general, the value of relatively flexible currency and monetary arrangements is that they allow the authorities the discretion to tailor policy settings to the needs of the domestic economy. But there are two important constraints on the adoption of discretionary currency and monetary policies in East Timor.

The first constraint is the country's limited financial, infrastructure and human resources. This constraint is such that it is probably not practical for East Timor to run its own discretionary currency and monetary policies. If this is so, the implication is that East Timor would probably be better to fix its exchange rate to that of a low-inflation economy and adopt that country's monetary policy as its own. This should enable it to secure a stable low inflationary macroeconomic environment.

The second constraint is the need to ensure that the system is robust to stress and changing circumstances over time. This is no small matter. The experience of Indonesia, PNG, and a number of other Pacific Island nations suggests that, despite the best of intentions, discretionary systems in developing countries can come undone over time due to political pressures and corruption. This is not to impugn the integrity of the East Timorese or in any way to suggest that East Timor is fated to go down this path. But it is too powerful a lesson to ignore. If this is right, the implication is that East Timor should adopt a 'strong form' of fixed exchange system, like a currency board or 'dollarisation' (that is officially use the currency of another country as its own).

While a currency board has the advantage of allowing East Timor to have its own currency, it is arguable that its interests may be better served by 'dollarising'. The argument is two-fold. First, 'dollarisation' is more likely to result in lower interest rates on average than a currency board, since currency boards are invariably tested in difficult times to see if the authorities will keep their resolve. This cannot happen when a country uses the currency of another. Second, under a currency board, the authorities have the discretion to change arrangements at any time they wish; the 'PNG problem' can still occur. Under 'dollarisation', the authorities can change the regime if they want to, but they cannot do so easily or without proper planning. 
If East Timor is to fix its currency to that of another country, realistically, it probably has only four choices: the euro, the rupiah, the US dollar, or the Australian dollar. All of these have advantages and disadvantages but the two most likely contenders are the US dollar and the Australian dollar. Both have different advantages and disadvantages, and the choice between the two is a matter of economic and political judgment.

The US dollar is attractive because it is the key world currency, can provide a stable low-inflation anchor, and is already in official use in East Timor. There are two problems with the US dollar.

First, the denomination of US dollar notes is too high for them to be used for many of the smaller transactions that take place in East Timor. US coins are too expensive to move, and too hard to understand since they are not all numbered. This problem can be solved by East Timor having its own coins (minted, say, in Australia) so long as they are fully backed by US notes.

The second problem is that the US dollar is very strong, which some fear would price East Timorese products out of the market, especially in comparison to Indonesian goods. This is a serious concern but needs to be kept in perspective. The US dollar is widely thought to be overvalued, and so has substantial scope to depreciate in the future, which would be beneficial to exports and import-competing goods. There is also scope for domestic prices to fall in East Timor, once better transport and information infrastructure is established outside Dili, trade with West Timor is normalised, and the expatriate community gets smaller when UNTAET is disbanded.

Moreover, while international competitiveness is obviously important, monetary policy must ultimately be directed at domestic price stability, and the exchange rate regime needs to support this. An implication of this is that the authorities need to ensure that East Timor's labour markets are as flexible as possible, so that wages can fall when prices fall, and that labour costs can fall when adverse economic disturbances occur, so that their negative effects on output and employment are as small as possible.

The Australian dollar is attractive because Australia is (and will likely continue to be) an important trading partner, it can provide a stable lowinflation anchor, it is a 'commodity currency' and so suits East Timor's commodity export orientation (albeit far from perfectly), and it is already relatively well accepted in East Timor. The main problems with fixing to the Australian dollar are the current low-cycle in the Australian dollar, how fixing to the Australian dollar would affect East Timor's (and Australia's) relationship with Indonesia, and whether it would create a mentality of dependence on Australia. 
This assessment has focused on the importance of limiting policy discretion in the currency and monetary system. This should not be interpreted as meaning that policymakers should have no discretion. Indeed, as economic circumstances change it is essential that policymakers have some tools to respond to them. ${ }^{10}$ The issue is whether it is better to do this with the exchange rate and monetary policy, or through fiscal policy. A tight currency and monetary system is more likely to secure better inflation and economic growth outcomes, but it also needs to be backed by a discretionary, yet disciplined, fiscal system to deal with serious economic disturbances as they occur.

$10 \quad$ I am grateful to Mardi Dungey for this point. 


\section{References}

Arndt, H.W. (1971), "The Future of New Guinea's Monetary System”, Economic Record, March, 38-46.

Blundell-Wignall, A. (ed.) (1993), The Exchange Rate, International Trade and the Balance of Payments, Proceedings of a Conference, Economic Group, Reserve Bank of Australia.

de Brouwer, G.J. (2000), "Should Pacific Island Nations Adopt the Australian Dollar?”, Pacific Economic Bulletin, 15(2), 161-169.

Drake, P.J. (1983), 'Monetary and Exchange Rate Management in Tiny, Open Underdeveloped Economies', Savings and Development, 1(VII), 519.

Duncan, R.C. (1999), Development Lessons for East Timor", Bulletin of Indonesian Economic Studies, 35(1), April, 129-132. .

Duncan, R.C. and X. Xu (2000), "Should Papua New Guinea Adopt a Stronger Exchange Rate Regime?", Pacific Economic Bulletin, 15(2), 3645 .

Friedman, M. (1953), "The Case for Flexible Exchange Rates", in Essays in Positive Economics, University of Chicago Press, Chicago.

Hausmann, R., M. Gavin, C. Pages-Serra and E. Stein (1999), Financial Turmoil and the Choice of Exchange Rate Regime, Inter-American Development Bank, Washington, D.C.

Isard, P. (1995), Exchange Rate Economics, Cambridge, Cambridge Surveys of Economic Literature, Cambridge University Press.

McLeod, R.H. (2000), 'Which Currency for East Timor?', Pacific Economic Bulletin, 15(1), 113-118.

Mussa, M., P. Masson, A. Swoboda, E. Jadresic, P. Mauro and A. Berg (2000), Exchange Rate Regimes in an Increasingly Integrated World, IMF, April.

Rivera-Batiz, L.A. and A.N.R. Sy (2000), "Currency Boards, Credibility, and Macroeconomic Behaviour", IMF Working Paper WP/00/97.

Schuler, K. (1999), "Dollarising Indonesia", Bulletin of Indonesian Economic Studies, 35(3), December, 97-113.

$\mathrm{Xu}, \mathrm{X}$. (1999), "The Exchange Rate Regime in Papua New Guinea Getting It Right”, Pacific Economic Bulletin, 14(2), 48-70. 